\title{
Uwarunkowania transformacji polityki energetycznej Francji. Między ekologiczną modernizacją a ekonomiczną kalkulacją
}

Transformacja energetyczna dotychczas kojarzyła się z Energiewende, czyli transformacją energetyczną w Niemczech. Tymczasem projekt ekologicznej modernizacji - szeroko integrujący wszystkie aspekty transformacji gospodarki - jest jednym ze sztandarowych pomysłów urzędującego prezydenta François Hollande'a i francuskich socjalistów. Francja jest drugim w Unii Europejskiej i w światowej czołówce największych konsumentów energii. Dotychczasowa polityka energetyczna Francji była skoncentrowana na efektywności energetycznej i standardach bezpieczeństwa energetyki jądrowej, w mniejszym stopniu zaś na rozwoju nowych zielonych źródeł energii. W ramach nowej polityki transformacji energetycznej, zaproponowano wiele inicjatyw w zakresie rozwoju energetyki odnawialnej, zbliżając się do niemieckiej wizji transformacji energetycznej, elity polityczne nad Sekwaną uznały, że rozwój OZE ma znaczenie strategiczne nie tylko dla zaspokojenia potrzeb energetycznych kraju, ale także - w obliczu zaostrzania reżimu ograniczenia emisji gazów cieplarnianych (GHG) - jest szansą na zbudowanie przewagi konkurencyjnej innowacyjnej gospodarki i stworzenie wielu nowych miejsc pracy. W efekcie, ekologiczna modernizacja gospodarki przez nieemisyjne innowacje technologiczne ma zapewnić postęp w osiagnnięciu celów środowiskowych $\mathrm{z}$ jednoczesnym postępem industrialnym i wzrostem gospodarczym (sustainable development).

\section{Bilans i uwarunkowania polityki energetycznej Francji}

Francja pod względem zasobów jest jednym z najskromniej obdarzonych przez naturę w surowce energetyczne krajem Europy. Okres silnego wzrostu gospodarczego w latach 1945-1973 (tzw. Trente Glorieuses - „trzydzieści lat chwały”) spowodował ogromne zapotrzebowanie kraju na paliwa kopalne, które pochodziły głównie z importu. Gdy kryzys naftowy lat 70. XX wieku, wstrząsnął gospodarkami wielu krajów świata, Francja przystąpiła do reorganizacji założeń polityki energetycznej, by ograniczyć zależność od importu ropy naftowej. W efekcie dynamicznego rozwoju programu cywilnej energetyki jądrowej (plan Pierre'a Messmera), pomiędzy 1973 a 2013 rokiem produkcja energii elektrycznej potroiła się, a ilość prądu wytworzonego przez elektrownie jądrowe wzrosła 75 razy (z 6 TWh do 424 TWh), stanowiąc $74 \%$ produkcji całkowitej (CGDD, 2014, s. 26). Uruchomienie przemysłowego programu rozwoju energetyki jądrowej, celem uniezależnienia produkcji energii elektrycznej od surowców zewnętrznych, zmieniło sytuację energetyczną Francji - udział trzech paliw kopalnych (węgla, ropy naf- 
towej i gazu ziemnego) w końcowym (finalnym) zużyciu energii we Francji nie przekracza dwóch trzecich (najmniej spośród wszystkich innych dużych gospodarek w UE) ${ }^{1}$.

Realizacja szerokiego programu budowy elektrowni atomowych doprowadziła do przebudowy struktury konsumowanych paliw. Program energetyki jądrowej, wprowadzany ponad podziałami politycznymi, doprowadził do znaczącego zmniejszenia zależności energetycznej i skompensował brak zasobów własnych, a także umożliwił odejście od wegla. Dzięki energetyce jądrowej Francja wypracowała unikatowy model bezpieczeństwa energetycznego. Wskaźnik import dependency (czyli zależność od zewnętrznych źródeł paliw, rozumiany jako stosunek energii wyprodukowanej ze źródeł pochodzących z importu do całkowitej ilości konsumowanej) dla Francji wynosi 50\% w porównaniu z 76\% w 1978 roku (INSEE, 2010; EU Commission Brochure, 1980, s. 24). Gdyby jednak wyłączyć energię jądrową z kategorii krajowego źródła energii, wówczas poziom zależności importowej Francji wzrósłby drastycznie do poziomu 80,5\% (CGDD, 2011, s. 8). Znaczący udział energetyki jądrowej w bilansie energetycznym Francji zapewnia nie tylko stabilność dostaw energii elektrycznej po konkurencyjnych cenach, lecz także niski poziom emisji gazów cieplarnianych, co ma kolosalne znaczenie w świetle unijnego systemu ich redukcji (EU Emissions Trading System). Produkcja energii elektrycznej stanowi zaledwie ok. $10 \%$ emisji $\mathrm{CO}_{2}$ we Francji (MÉDDÉ, 2009).

Proklamacja „niezależności energetycznej Francji” jest zatem złudna i może dotyczyć jedynie sektora elektroenergetycznego. Dzieje się tak, ponieważ całkowita konsumpcja ropy naftowej od lat 70 . XX wieku znacznie wrosła, a jej import wynosi niemal 100\% zapotrzebowania, podobnie w przypadku gazu ziemnego (98\%). Francji udało się natomiast wzorcowo zdywersyfikować kierunki importu surowców energetycznych (bliskowschodni, kraje Afryki Północnej, Północ Europy - Norwegia, oraz wschodni - Rosja).

Francja posiada bogaty - aczkolwiek z wyjątkiem energetyki wodnej stosunkowo mało wykorzystany - potencjał odnawialnych źródeł energii. Dominacja energetyki jądrowej spowodowała istotne zapóźnienia i brak spójnej strategii politycznej i gospodarczej wobec rozwoju OZE (z wyjątkiem energetyki wodnej z ok. 25\% udziałem w produkcji energii pierwotnej na tle innych źródeł odnawialnych i drugie źródło elektryczności ok. 13\%) ${ }^{2}$. Podstawowym mankamentem jest niewielka dywersyfikacja nowych źródeł odnawialnych energii, albowiem udział energetyki wiatrowej i słonecznej w produkcji elektryczności jest nadal bardzo niewielki. Francja posiada także duży potencjał produkcji energii z pływów wód oceanicznych, stąd inwestycje EDF na wybrzeżach Bretanii.

Francja, po latach zapóźnienia w rozwoju zielonych energii, dynamicznie przyspieszyła i ukierunkowuje założenia polityki energetycznej, opierając je nie tylko, jak dotychczas, na dominującym znaczeniu energetyki jądrowej, ale na dynamicznym rozwoju odnawianych źródeł energii. Nowe kierunki dla polityki energetycznej Francji

1 Konsumowana energia finalna składa się z węgla, ropy naftowej, gazu, energii elektrycznej oraz odnawialnych źródeł energii cieplnej, przy czym energetyka nuklearna pokrywa ok. 20\% zapotrzebowania na energię finalną.

${ }^{2}$ We Francji istnieje prawie 600 hydroelektrowni (przeplywowych i szczytowo-pompowych). 
wyznaczył proces Grenelle de l'environnement negocjowany od 2007 roku z udziałem przedstawicieli władz regionalnych, związków zawodowych i pracodawców oraz organizacji pozarządowych w celu ustalenia planów działania w zakresie zrównoważonego rozwoju. Program ten wyznaczył ambitne cele dla poszczególnych sektorów i źródeł czystej energii. Obszary priorytetowe objęły ograniczenie emisji w budownictwie i sektorze transportowym. Prawo Grenelle z 3 sierpnia 2009 roku zawierało postulat przygotowania narodowego planu dostosowań do zmian klimatu, ukierunkowanego na wspieranie działań adaptacyjnych, by przygotować państwo do funkcjonowania w nowych warunkach klimatycznych (Loi no 2009-967; MÉDDTL, 2011). Pierwszy narodowy plan składał się z 84 działań wyrażanych przez 230 środków i zawierał odniesienia do rozwoju zielonej gospodarki (Plan de l'économie métiers verte). Równolegle pod koniec 2012 roku we Francji zainaugurowano Narodową Debatę nad Transformacją Energetyczną (DNTE), która włączając rząd, związki zawodowe i pracodawców, organizacje ekologiczne i samorządy, miała za zadanie wypracować ramy dla przyszłości energetycznej Francji.

\section{Gospodarcze i ekologiczne znaczenie energetyki jądrowej}

Energia jądrowa, która stanowi integralny element polityki energetycznej Francji, spełnia trzy fundamentalne cele: zwiększa niezależność energetyczną kraju i bezpieczeństwo dostaw, zapewnia niskie i stabilne ceny energii elektrycznej (co zwiększa konkurencyjność francuskiej gospodarki, szczególnie w sektorach o dużym zapotrzebowaniu na energię elektryczną) oraz stanowi instrument walki z globalnym ociepleniem.

Energetyka jądrowa ma priorytetowe znaczenie ekonomiczne i strategiczne dla Francji - bilansuje ponad 1/3 kosztów importu paliw kopalnych. Przemysł jądrowy obecnie jest ważnym atutem i ogniwem gospodarki państwa, dając zatrudnienie ponad 100 tys. osób (od budowy przez eksploatację i produkcję paliwa jądrowego po składowanie odpadów). Eksport energii elektrycznej (do Włoch, Szwajcarii, Hiszpanii, Holandii, Niemiec) stanowi ważne źródło dodatkowych przychodów. Dodatkowe korzyści ekonomiczne wynikają z niskiej emisyjności francuskiego sektora energii elektrycznej wobec zaostrzania europejskiego systemu kwotowania emisji gazów cieplarnianych (EU ETS/Emissions Trading System). Dzięki energetyce jądrowej Francja nie tylko ograniczyła import paliw kopalnych, ale stała się głównym dostawcą produktów i usług dla przemysłu jądrowego. Francja nieustannie popularyzuje „elektryczność jądrową" a w 2008 roku utworzono nawet Agence France Nucléaire International (AFNI), do zadań której należy promocja handlu cywilnymi technologiami nuklearnymi (ekspertyzy, konsultacje, doradztwo). W czerwcu 2011 roku z inicjatywy rządu powstał International Institute for Nuclear Energy w Paryżu z zadaniem międzynarodowej współpracy, w tym szkoleń, celem budowania i wzmacniania bezpieczeństwa jądrowego i kultury bezpieczeństwa w dziedzinie energii jądrowej.

Francja jest gorącą orędowniczką zaostrzania międzynarodowego reżimu przeciwdziałania zmianom klimatu, będąc gospodarką o jednej z najniższej intensywności emisji $\mathrm{CO}_{2} / \mathrm{PKB}$ na świecie (Szarka, 2011, s. 114). Rozwinięty program energetyki jądrowej spowodował, że emisja GHG na mieszkańca jest 23\% mniejsza niż średnia 
UE i 45\% mniej niż średnia światowa (2010). Francja jest jednym z nielicznych krajów, którym udało się połączyć dwa cele: wzrost gospodarczy i ograniczenie emisji GHG. Dlatego, kraj ten jest bardzo silnie zaangażowany w ksztaltowanie europejskich i międzynarodowych norm polityki klimatycznej. Te szczególne uwarunkowania stanowią podstawę aspiracji Francji do przywództwa w polityce klimatycznej w UE i na płaszczyźnie międzynarodowej. Co więcej, Francja zabiega o uznanie energetyki jądrowej jako czyste źródło energii w ramach mechanizmu czystego rozwoju (Clean Development Mechanism) zdefiniowanego w protokole z Kioto. Dotychczas się to nie udało mimo wsparcia Stanów Zjednoczonych i Chin. Nie udało się też uzyskać szerszego poparcia dla proponowanej zasady pomiaru carbon intensity według emisji $\mathrm{CO}_{2}$ per capita, która dla Francji jest bardzo korzystna (Szarka, 2011, s. 116). Niemniej jednak, Francja nie ustaje $\mathrm{w}$ dążeniach, by energetyka jądrowa została uznana za czyste źródło energii obok OZE i w ramach niskowęglowych źródeł energii razem $\mathrm{z}$ technologią czystego węgla (clean coal technology).

\section{Francusko-niemieckie partnerstwo w przemyśle ,zielonych” technologii}

Decyzja Niemiec o wycofaniu się z energetyki jądrowej po katastrofie w Fukushimie rozpoczęła we Francji publiczną debatę o przyszłości tej branży. W prezydenckiej kampanii wyborczej w 2012 roku po latach trwania konsensusu, temat przyszłości energetyki jądrowej został pierwszy raz w historii V Republiki tak bardzo upolityczniony, a debata publiczna ogromnie spolaryzowała scenę polityczną. Ówczesny kandydat na prezydenta, François Hollande zadeklarował zamknięcie 24 spośród 58 reaktorów i zmniejszenie ich udziału w produkcji prądu do 2025 roku z 75 do $50 \%$, z równoczesnym wzrostem znaczenia energii odnawialnej poprzez system wsparcia dla silnego rozwoju OZE jako formy kreowania miejsc pracy (Hollande, 2011). W ten sposób Francja realizuje scenariusz odrobienia zapóźnień $\mathrm{w}$ dziedzinie energetyki odnawialnej w stosunku do Niemiec ( 371 tys. miejsc pracy w sektorze OZE wobec 176 tys. we Francji w 2013 roku; IRENA, 2015, s. 9; Bajczuk, 2013, s. 5).

Nad Sekwaną, gdzie wysoki poziom bezrobocia od dwóch dekad jest poważnym problemem, rozwój ,zielonej energii" jest postrzegany jako jeden z najlepszych sposobów na tworzenie nowych miejsc pracy i ożywienie gospodarcze. Prezydent F. Hollande zapowiedział pogłębienie współpracy w zakresie energii odnawialnej z Niemcami. Koordynacja działań miałaby polegać przede wszystkim na stworzeniu dużego przedsiębiorstwa (konsorcjum) energetycznego w sektorze odnawialnych źródeł energii (Élysée, 2014). Francja przyłączyła się też do niemieckiej inicjatywy zızeszenia 10 państw (w tzw. Renewables Club; m.in. Chiny, Indie i Wielka Brytania), na które przypada ponad $40 \%$ globalnych inwestycji w OZE. Celem tej inicjatywy jest transformacja światowej energetyki, by OZE miały dominującą pozycję w produkcji energii.

Na poziomie bilateralnym zarówno niemiecka, jak i francuska polityka energetyczna zakłada zwiększenie potencjału odnawialnych źródeł energii. 19 lutego 2014 r., francusko-niemiecka Rada Ministrów uzgodniła przyjęcie wspólnego stanowiska w sprawie współpracy na rzecz przeciwdziałania zmianom klimatycznym do $2030 \mathrm{roku}$ (Présidence de la République, 2014a; Présidence de la République, 2014b). Oba kraje 
uzgodniły, ustanowienie wiążącego celu redukcji emisji GHG o 40\% w UE 2030 r. w porównaniu do poziomu z 1990 roku oraz wzrostu udziału OZE w UE do poziomu $27 \%$ (wpisując się w propozycje KE), określenie europejskich ram finansowania OZE i programu efektywności energetycznej, a także listy sektorów zagrożonych migracją przemysłu poza obszar objęty restrykcjami EU ETS, w tym stworzenie wiarygodnego systemu zapobiegania temu zjawisku, poprzez wsparcie dla bardzo energochłonnych gałęzi przemysłu. Ponadto, na wspólnym posiedzeniu Rady Ministrów ogłoszono zawiązanie francusko-niemieckiego partnerstwa przemysłowo-technologicznego realizowanego przez grupę wysokiego szczebla reprezentującą obydwa rządy. Objęło ono obszary współpracy przemysłowej w zakresie rozwoju technologii inteligentnych sieci przesyłu energii elektrycznej, technologii energetyki słonecznej i wodorowej, efektywności energetycznej i magazynowania energii elektrycznej ze źródeł odnawialnych, a także rozwój badań naukowych. Określono także instytucje partnerskie mające wspierać tę współpracę (Présidence de la République, 2014b):

- francuska Agencja Środowiska i Zarządzania Energią (ADEME) i Niemiecka Agencja Energetyczna (DENA);

- francusko-niemieckie biuro na rzecz rozwoju energetyki odnawialnej OFAEnR (L'Office franco-allemand pour les énergies renouvelables);

- organizacje badawcze m.in. francuski instytut nafty i nowych źródeł energii/Institut Français du Pétrole Energies nouvelles (IFP), Francuska Komisja ds. Energii Atomowej CEA, niemieckie uniwersytety techniczne z Karlsruhe, Monachium;

- publiczne instytucje finansujace strategiczne obszary dhugofalowych inwestycji (francuska Caisse des Dépôts, czy niemiecki państwowy bank rozwoju KfW/ Kreditanstalt für Wiederaufbau).

W kolejnym etapie, planuje się przygotowanie wspólnej strategii przemysłowo-technologicznej, a w przyszłości powołanie wspólnego konsorcjum produkującego komponenty dla urządzeń przemysłu energetyki odnawialnej (paneli fotowoltaicznych, turbin wiatrowych itp.) ukierunkowanego na eksport technologii niskoemisyjnych i rozbudowę inteligentnych sieci (smart grids).

Francja dąży do zacieśnienia współpracy, gdyż widzi przewagę niemieckiego modelu gospodarczego (Młynarski, 2013). Gospodarka Niemiec ma wymiar globalny, osiągając 198 mld euro nadwyżki w handlu światowym podczas, gdy Francja rejestruje rekordowy deficyt $w$ handlu na poziomie 76 mld euro (Eurostat, 2012-13).

W efekcie zawartego porozumienia Francja liczy, iż wraz z Niemcami stanie się centrum światowej dyplomacji klimatycznej. Niemcy przez walkę z globalnym ociepleniem znalazły drogę do promocji dynamicznie rosnącego sektora ,zielonych technologii” narodowej gospodarki. Francja chce się przyłączyć do tego pomysłu, a współpraca ma służyć interesom ekonomicznym obydwu państw.

\section{„Nowa” polityka energetyczna Francji}

Transformacja francuskiej polityki energetycznej wpisuje się w kontekst globalny przede wszystkim poprzez przeciwdziałanie zmianom klimatycznym. W czerwcu 2014 roku zaprezentowane zostały przez Minister Ekologii, Trwałego Rozwoju i Energii 
Ségolène Royal założenia rządowego projektu ustawy o transformacji energetycznej (MÉDDÉ, 2014a). Projekt jest bardzo szeroki i obejmuje różne kierunki reform, takie m.in. jak: zmniejszenie kosztów energii w skali kraju, zapewnienie bezpieczeństwa dostaw, redukcję emisji gazów cieplarnianych i zużycia paliw kopalnych oraz wzrost odnawialnych źródeł w koszyku energetycznym, promocję projektów efektywności energetycznej ${ }^{3}$. Minister Ségolène Royal, ogłosiła uruchomienie 10 mld euro wydatków budżetowych w ciągu trzech lat dla rozpoczęcia procesu transformacji (finansowanie wsparcia przeznaczone m.in. na ulgi podatkowe, kredyty dla inwestycji w energooszczędność i różne mechanizmy stymulujące inwestycje w OZE), które mają zaowocować m.in. stworzeniem 100 tys. miejsc pracy w sektorze „zielonego wzrostu” („Le Monde”, 2014). Jak stwierdziła minister Royal nowe prawo ma zapewnić „zrównoważony rozwój, miejsca pracy i postęp społeczny”, przyczyniając się do „walki ze zmianami klimatu" i zmniejszenia wydatków za energię Francji, które wynoszą prawie 70 mld euro rocznie („Le Monde”, 2014).

Główne założenia transformacji energetycznej we Francji obejmują zmianę modelu energetycznego opartego o paliwa kopalne poprzez promowanie „zielonego wzrostu” i efektywności energetycznej, przy stopniowym zmniejszanie udziału energetyki jądrowej. Najważniejsze cele francuskiej transformacji energetycznej (projekt ustawy transformacji energetycznej dla zielonego wzrostu/transition énergétique pour la croissance verte po poprawkach Senatu z 15 lipca 2015 roku) zakładają (Sénat RF, 2015):

- zmniejszenie końcowego zużycia energii o $20 \%$ w 2030 i o $50 \%$ w roku 2050 wobec roku 2012, zwłaszcza poprzez inwestycje w sektorach budownictwa i transportu;

- zmniejszenie zużycia paliw kopalnych (ropa, gaz, weggiel) o 30\% do 2030 roku w stosunku do roku 2012 (głównie transport, np. poprzez rozpowszechnienie samochodów elektrycznych);

- zmniejszenie emisji GHG o $40 \%$ do 2030 wobec 1990 roku i o $75 \%$ do $2050^{4}$;

- wzrost udziału energetyki odnawialnej z 14\% w 2012 roku do poziomu $23 \%$ w końcowym zużyciu energii brutto w 2020 roku i 32\% w 2030 roku, przy czym z OZE ma pochodzić $40 \%$ w konsumowanej energii elektrycznej (rozwój energetyki wiatrowej i fotowoltaiki) ${ }^{5}$;

- zmniejszenie udziału energii jądrowej w produkcji energii elektrycznej z 75\% do $50 \%$ do 2025 roku pod warunkiem utrzymania konkurencyjnej ceny energii elektrycznej i przy zapewnieniu braku wzrostu emisji $\mathrm{GHG}^{6}$.

3 W ustawie znalazly się nawet takie założenia jak ograniczenie o $30 \%$ do 2020 roku przez instytucje państwowe i władze lokalne zużycia papieru biurowego, wycofanie plastikowych toreb kasowych, czy ograniczenie poziomu odpadów spożywczych, wsparcie projektów promujących recykling.

4 Cel ten zadeklarowany jeszcze przez prezydenta J. Chiraca, został podtrzymany przez premiera J.-P. Raffarina 19 lutego 2003 roku na 20. sesji plenarnej Międzyrządowego Zespołu ds. Zmian Klimatu (IPCC) w Paryżu, gdzie zadeklarowano „mnożnik cztery” (fr. le facteur quatre) obejmujący redukcję emisji GHG o $75 \%$ do 2050 roku (zapisany w art. 2 ustawy z 13 lipca 2005 roku o kierunkach polityki energetycznej Francji).

Dyrektywa 2009/28/WE z dnia 23 kwietnia 2009 roku w sprawie energii odnawialnej ustanowiła dla Francji cel 23\% energii z OZE w zużyciu energii końcowym brutto do 2020 roku.

${ }^{6} \mathrm{~W}$ marcu 2015 roku Senat wbrew opinii rządu usunąl termin 2025 roku z projektu socjalistycznego rządu Manuela Valls'a, w którym ma nastappić zmniejszenie udziału EJ do $50 \%$ w produkcji energii elektrycznej, jednak Zgromadzenie Narodowe (lipiec 2015) ostatecznie przywrócilo tę cezurę czasową. 
Transformacja ma zatem - inaczej niż w Niemczech, gdzie do 2022 roku mają zostać zamknięte wszystkie elektrownie jądrowe - dokonać się nie tyle kosztem ograniczenia wykorzystania energii jądrowej, ale poprzez wzrost wykorzystania źródeł odnawialnych i efektywności energetycznej. We Francji całkowite odrzucenie energetyki jądrowej jest niemożliwe w dającej się przewidzieć perspektywie czasowej. Prowadziłoby to do gwałtownego wzrostu importu surowców energetycznych i paliw, a w ślad za tym zaburzenia bilansu handlowego i zmniejszenie PKB, konkurencyjności francuskiej gospodarki, osłabienia siły nabywczej obywateli ze względu na wzrost cen energii elektrycznej, utraty miejsc pracy ponad 100 tys. zatrudnionych bezpośrednio w sektorze i wśród podwykonawców, a nade wszystko trudności w wywiązaniu się z celów polityki klimatycznej UE (Młynarski, 2013, s. 100-101, 109-110). Produkcja energii elektrycznej zostanie zatem utrzymana na dotychczasowym stałym poziomie $(63,2 \mathrm{GW})$ - w tym celu planuje sie przedłużenie żywotności reaktorów, których odłączenie będzie następować systematycznie w miarę włączania nowych źródeł odnawialnych (Réseau „Sortir du nucléaire”, 2015) Nowa polityka energetyczna nie zakłada zamykania żadnego z obecnie eksploatowanych reaktorów, gdyż - jak twierdzi minister Royal - energetyka jądrowa umożliwi dokonanie transformacji francuskiego bilansu energetycznego w sposób niezakłócony i ewolucyjny (Gay, 2015; Cognasse, Dupin, Gateaud, 2015) ${ }^{8}$. Należy zaznaczyć, iż stan techniczny francuskiej floty atomowej pozostawia dużo do życzenia. Spośród 19 elektrowni (58 reaktorów), które są rozmieszczone na terenie całego kraju, zwłaszcza w pobliżu dużych rzek lub na wybrzeżu morskim, aż 22 osiagnie 40-letni okres pracy w 2022 roku (Młynarski, 2013, s. 110). Dlatego, EDF chce przedłużenia okresu żywotności reaktorów z 40 do 50, a nawet 60 lat, bowiem wymiana na nowe bloki związana byłaby ze znacznym wysiłkiem finansowym. Ponieważ krajowe zużycie - i produkcja - energii mają rosnąć, to cała moc ponad limitem ma pochodzić ze źródeł odnawialnych.

Reforma zakłada dynamiczny rozwój $i$ integrację z systemem energetycznym źródeł odnawialnych, które mają wypełnić lukę w ograniczaniu udziału energetyki jądrowej w produkcji energii elektrycznej. Projekt nowej ustawy nawiązuje do wcześniejszych aktów m.in. prawa Grenelle de l'environnement, które ustanowiło cel zwiększenia udziału energii wiatrowej z $6 \mathrm{GW}$ do $19 \mathrm{GW}$ na lądzie oraz dodatkowe $6 \mathrm{GW}$ z morskich elektrowni wiatrowych do 2020 roku. Cele te mogą okazać się jednak trudne do osiagnięcia, w sytuacji kalkulacji kosztów instalacji energetyki wiatrowej wobec relatywnie niskich kosztów energii elektrycznej uzyskiwanej wciąż z atomu. Szybki rozwój instalacji odnawialnych mają stymulować specjalne taryfy dla energii elektrycznej produkowanej z OZE, ułatwienia przepisów w tym dla innowacyjnych projektów samorządowych oraz instrumenty finansowego wsparcia inwestycyjnego (w tym 5 mld euro na pożyczki dla władz lokalnych od państwa na realizację celów transformacji energetycznej) i badań rozwojowych ${ }^{9}$.

7 Senat wykorzystując silną pozycję Republikanów przegłosował poprawki (ostatecznie odrzucone) by podnieść pulap do $64,85 \mathrm{GW}$.

8 Utrzymanie dotychczasowego w praktyce będzie oznaczało konieczność zamknięcia jednego ze starszych reaktorów, po uruchomieniu nowego reaktora trzeciej generacji w Flamanville (Manche).

9 Rząd zapowiedzial pozyskanie środków finansowych m.in. z: La Caisse des dépôts et consignation (CDC) - 5 mld euro; la Banque publique d'investissement (BEI lub Bpifrance) - 1 mld euro, Europejski Bank Inwestycyjny - kolejny 1 mld euro. 
Kolejnym filarem reformy jest zwiększenie efektywności wykorzystania energii w sektorze transportu i budownictwa. Ponieważ Francja, dzięki dużej proporcji energetyki jądrowej, emituje niewiele $\mathrm{CO}_{2} \mathrm{w}$ sektorze produkcji energii, poprawa efektywności energetycznej ma nastąpić w budownictwie i transporcie. W sektorze mieszkalnictwa (który stanowi prawie połowę zużycia energii w kraju) działania obejmować będą m.in. obowiązkową termomodernizację budynków (do 2025 roku dla prywatnych budynków mieszkalnych) i ich konwergencję na obiekty o niskim zużyciu, montaż tzw. instalacji elektrycznych ,inteligentnych" liczników, a także dostosowanie istniejącego prawa w celu ułatwienia realizacji innowacyjnych projektów. Wśród instrumentów wsparcia znajdują się m.in. bezprocentowe pożyczki (stworzenie Narodowego Funduszu Gwarancyjnego) dla kupujących dom po raz pierwszy jeśli budynek spełnia standardy ponad te określone w przepisach budowlanych, czyli jest energooszczędny lub o niskim zużyciu energii (BBC - bâtiments basse consommation) i $\mathrm{BEPOS} \mathrm{-} \mathrm{bâtiments} \mathrm{à} \mathrm{énergi-}$ epositive). Inne instrumenty wsparcia to $\mathrm{m}$.in. ulgi podatkowe dla przebudowy już istniejących domów.

Sektorem, w którym upatruje się znaczącego obniżenia emisji $\mathrm{CO}_{2}$ jest sektor transportu, który obok ciepłownictwa jest głównym źródłem emisji (odpowiedzialnym za ponad jedną czwartą emisji GHG). Reforma zakłada intensywne prace nad poprawą parametrów i opłacalności rozwoju czystego transportu napędzanego silnikami elektrycznymi ${ }^{10}$. Liczba punktów ładowania ma wzrosnąć z obecnych 10 tys. do $7 \mathrm{mln}$ w 2030 roku (MÉDDÉ, 2014b). Rozwój tego sektora przemysłu motoryzacyjnego ma wspomóc system „bonusów elektrycznych” (nawet do 10000 euro celem pozbywania się samochodów z silnikiem diesla i zamiany ich na pojazdy o napędzie elektrycznym - MÉDDÉ, 2015; JORF, 2015). Firmy zatrudniające powyżej stu pracowników będą zobowiązane do opracowania „planu mobilności” zachęcającego ich do korzystania $z$ transportu publicznego. Odnawialna flota pojazdów wykorzystywana przez instytucje publiczne będzie musiała w co najmniej 50\% opierać się o modele niskiej emisji (dotyczy to także przedsiębiorstw taksówkarskich i wypożyczalni samochodów do $10 \%$ ich floty). Ponadto planuje się rozbudowę technologii akumulatorowych w celu magazynowania energii.

Ustawa przewiduje także czterokrotny wzrost opodatkowania „klimat-energia” („,contribution climat énergie”/(CCE) od wszystkich paliw kopalnych, zależnie od generowanej przez nie emisji), co oznacza wzrost podatku weglowego (obecnie 14,5 euro za tonę $\mathrm{CO}_{2}$ do 22 euro/t $\mathrm{CO}_{2}$ od 2016 roku, 56 euro/t $\mathrm{CO}_{2}$ w 2022 roku i 100 euro/t $\mathrm{CO}_{2}$ w 2030 roku), aby skutecznie zachęcić przemysł do redukcji emisji ${ }^{11}$.

Projekt ustawy o transformacji energetycznej, od jesieni 2014 do połowy 2015 roku stanowił przedmiot ostrych sporów między socjalistami - zwolennikami rozwoju OZE i republikanami - opowiadającymi się za utrzymaniem roli energetyki jądrowej. Debata narodowa nad przyszłością i kierunkami francuskiej transformacji energetycznej (w szczególności wizja wykorzystania energetyki jądrowej) spolaryzowała krajową

${ }^{10}$ Prognozuje się, że do 2020 r. we Francji będzie 2-3 miliony elektrycznych samochodów, a ich ladowanie ma odbywać się w domu lub z sieci publicznej.

${ }^{11}$ Mechanizm CCE nie obejmuje podatku od paliw motoryzacyjnych (TICPE, la taxe intérieure de consommation sur les produits énergétiques). 
scenę polityczną. Ustawa o transformacji energetycznej została ostatecznie zatwierdzona 22 lipca 2015 roku, niemal pół roku przed oenzetowską konferencją klimatyczną, dzięki czemu Paryż będzie mógł pełnić rolę „wzorcowego” gospodarza światowej konferencji klimatycznej w Paryżu (COP21) w grudniu br. Pierwsze dekrety wykonawcze zostaną opublikowane jesienią 2015 roku, a postępy w realizacji wieloletniego planu niskoemisyjnej modernizacji kraju podlegać będą cyklicznym przeglądom i ocenom.

\section{Nie tylko ekologia ... COP21 w Paryżu}

Francja będzie gospodarzem Konferencji Klimatycznej Narodów Zjednoczonych COP21 COP 21/CMP11 (30 listopad-11 grudzień 2015), podczas której ma zostać podpisane globalne porozumienie o zmniejszeniu emisji gazów cieplarnianych ${ }^{12}$. Wdrożenie reformy będzie sprawą prestiżową dla Francji, która ma ambicje doprowadzenia do nowego globalnego porozumienia klimatycznego (tzw. ,protokół paryski”" do UNFCCC), które zastąpi protokół z Kioto (jego postanowienia wygasną w 2020 r.) i określi nowe zobowiązania dotyczące ograniczania emisji gazów cieplarnianych.

Celem konferencji będzie doprowadzenie do szerokiego porozumienia dotyczącego zmniejszenia emisji gazów cieplarnianych. UE zadeklarowała cel redukcyjny GHG w postaci obniżenia swoich wewnętrznych emisji o $40 \%$ do $2030 \mathrm{r}$., w stosunku do poziomu z 1990 r. (cel ten został już uzgodniony przez Radę Europejską w październiku 2014 r.). Komisja Europejska, przedstawiając swoją wizję nowego porozumienia klimatycznego, zwraca uwagę, że powinno ono zobowiązywać nie tylko do redukcji emisji, ale także zachęcać wszystkie państwa do udziału w finansowaniu działań ochronnych oraz do rozwoju i transferu niskoemisyjnych technologii, a także do wzmacniania potencjału krajów najbardziej narażonych na zmiany klimatu.

Francja, która jest promotorem polityki klimatycznej na arenie międzynarodowej, wpisuje założenia ekologicznej modernizacji francuskiego przemysłu energetycznego w walkę z globalnym ociepleniem. W ocenie francuskich elit, promocja gospodarki niskoemisyjnej (low-emission economy) w praktyce sprzyja technologiom nieemitującym $\mathrm{CO}_{2}$ w sytuacji, gdy energetyka odpowiada za niemal $70 \%$ światowej antropogenicznej emisji gazów cieplarnianych, przez co stanowi istotny problem bezpieczeństwa ekologicznego i zanieczyszczenia atmosfery w skali globalnej (IEA, 2014, s. 7-8). Z punktu widzenia konieczności przeciwdziałania zmianom klimatu, pośrednim rozwiązaniem - zgodnym z założeniami ekologiczno-ekonomicznej modernizacji francuskiego sektora energetyki - jest zastępowanie paliw kopalnych alternatywnymi niskolub nieemisyjnymi źródłami energii, a więc odnawialnymi źródłami energii (OZE) i paliwem jądrowym. Toteż, zaangażowanie Francji w negocjacjach w celu osiągnięcia

12 Zgodnie z przyjętym harmonogramem prac podczas 17. konferencji (COP17) stron Ramowej Konwencji w sprawie Zmian Klimatu, połączonej z 7. konferencją stron Protokohu z Kioto (CMP-7) w dniach 29 listopada-11 grudnia 2011 roku w Durbanie - która przyniosla oczekiwane przedłużenie obowiązywania po roku 2012 Protokolu z Kioto - uzgodniono potrzebę wypracowania nowego porozumienia klimatycznego obowiązującego po 2020 roku (190 krajów złożyło deklarację woli podpisania planu dojścia do nowego globalnego porozumienia o ochronie klimatu). 
szerokiego konsensusu na rzecz globalnego porozumienia klimatycznego wpisuje się nie tylko w konieczność zaspokojenia potrzeb energetycznych kraju, ale także zbudowania przewagi konkurencyjnej innowacyjnej gospodarki i stworzeniu wielu nowych miejsc pracy.

Plany francuskiej transformacji energetycznej są częścią przygotowania gospodarki kraju do europejskiego (EU ETS) i międzynarodowego (post-Kioto) systemu ograniczania emisji GHG, a określenie nowych ram globalnego porozumienia klimatycznego, jest kluczowe nie tylko dla utrzymania wiarygodności UE, ale efektywności dalszych starań o ograniczenie negatywnych skutków globalnego ocieplenia. Równocześnie, w ocenie francuskich polityków rozwój międzynarodowego reżimu przeciwdziałania zmianom klimatu może być silnym bodźcem do promocji eksportu urządzeń przemysłowych o niskiej emisji dwutlenku węgla. Stwarza to uwarunkowania do rozwoju dotychczasowego sektora przemysłu, w którym Francja utrzymuje od kilku dekad przewage know-how (energetyka jądrowa) i nowej gałęzi gospodarki - energetyki odnawialnej. Ekologiczna modernizacja ma zapewnić osiągnięcie celów środowiskowych $\mathrm{z}$ jednoczesnym postępem industrialnym i wzrostem gospodarczym (sustainable development). W ten sposób polityka klimatyczna ma stanowić narzędzie zwiększenia konkurencyjności francuskiej gospodarki na rynku globalnym.

\section{Wnioski}

- Francja próbuje pogodzić dotychczasową politykę utrzymania dominującej roli energetyki jądrowej z rozwojem nowoczesnych źródeł energii. Transformacja energetyczna oparta o zwiększenie udziału OZE w koszyku energetycznym wiąże się $\mathrm{z}$ realnymi korzyściami społeczno-ekonomicznymi takimi jak łagodzenie skutków zmian klimatu, wpływ na zdrowie oraz zwiększenie niezależności energetycznej i elastyczności systemu energetycznego. Francja - w ślad za Niemcami - podejmuje próby przeprowadzenia transformacji energetycznej, której podstawowym założeniem jest wyjście z ram monokultury jądrowej, a zaawansowany wiek floty reaktorów zmusza Francję do poszukiwania nowych rozwiązań dywersyfikacji koszyka energetycznego w oparciu o odnawialne źródła energii i efektywność energetyczną. Francja, planując zmniejszenie ilości energii pochodzącej z atomu, nie zamierza jednak na wzór Niemiec całkowicie z niej zrezygnować. Szybkie wycofanie się $z$ energetyki jądrowej jest nierealne, aczkolwiek kraj ten, kierując się względami ekonomicznymi, politycznymi i bezpieczeństwa będzie komplementarnie i stopniowo rozwijać odnawialne źródła energii.

- Przemysł związany z OZE ma w przyszłości dać ogromną ilość miejsc pracy, co wpisuje się we francuską strategię gospodarczą nastawioną na eksport i pobudzenie krajowego rynku pracy. Aktywna współpraca $z$ Niemcami, ma na celu zbudowanie konkurencyjnej przewagi w zakresie energetyki odnawialnej. Wynika to ze wspólnego interesu definiowanego w kategoriach rozwoju nowego sektora gospodarki, sprzyjającego tworzeniu miejsc pracy i eksportowi niskoemisyjnych technologii produkcji energii. Francuscy liderzy zdają sobie sprawę, że rozwój międzynarodowego reżimu przeciwdziałania zmianom klimatu może stać się silnym bodźcem dla 
promocji urządzeń przemysłowych o niskiej emisji dwutlenku węgla, toteż, walka z globalnym ociepleniem otwiera przestrzeń szerszego wykorzystania energetyki odnawialnej i energetyki jądrowej, które charakteryzuje relatywnie niewielkie oddziaływanie na środowisko naturalne.

- Transformacja energetyczna stanowi zatem wyraz pragmatyzmu Francji, która energetykę jądrową, jak również OZE postrzega jako środek do ograniczenia zależności od paliw kopalnych, a zarazem szansę uzyskania przewagi konkurencyjnej w epoce coraz bardziej popularnych niskoemisyjnych źródeł energii. Wdrożenie źródeł odnawialnych, to nie tylko konieczność zrównoważonego rozwoju, ale także szansa ekonomiczna, albowiem dynamicznie rosnący sektor gospodarki w oparciu o przewage technologiczną sprzyja uzyskaniu przewagi konkurencyjnej i stymuluje pobudzenie ekonomiczne w postaci wzrostu zatrudnienia i PKB oraz poprawy bilansu handlowego. Utrzymanie w bilansie energetycznym kraju strategicznej roli energetyki jądrowej może jednak utrudnić kapitałochłonne wdrażanie technologii energetyki odnawialnej (wiatrowej - lądowej lub morskiej i słonecznej), ze względu na wciąż konkurencyjne ceny energii elektrycznej z atomu.

\section{Bibliografia}

Bajczuk R. (2013), Ochrona klimatu - specjalność niemieckiego eksportu i dyplomacji, Ośrodek Studiów Wschodnich, nr 104.

CGDD (2011), Chiffres clés de l'énergie, Édition.

CGDD (2014), Chiffres clés de l'énergie 2014, Commissariat Général au Développement

Durable (2015), Service de l'observation et des statistiques, Édition.

Cognasse O., Dupin L., Gateaud P., L'Usine de l'Energie, 13.01.2015, http://www.usinenouvelle.com/ article/segolene-royal-il-faut-batir-de-nouvelles-centrales-nucleaires.N307067.

Élysée (2014), Ouverture de la conférence de presse du président de la République au Palais de l'Élysée le 14 janvier 2014, http://www.elysee.fr/declarations/article/ouverture-de-la-conference-de-presse-du-president-de-la-republique-au-palais-de-l-elysee-le-14-janvier-201, 6.07.2015.

EU Commission Brochure (1980), The European Community and the Energy Problem, European Documentation nr 2, European Documentation.

Eurostat (2012-2013), EU international trade 2012-13, http://ec.europa.eu/eurostat/statistics-explained/ index.php/File:International_trade,_2012-13_YB15.png, 20.06.2015.

Gay M. (2015), Le nucléaire est le cśur de la transition énergétique, Contrepoints, 8.03.2015, http://www.contrepoints.org/2015/03/08/200358-le-nucleaire-est-le-coeur-de-la-transition-energetique, 15.07.2015.

Hollande F. (2011), Réussir la transition énergétique, „Le Monde”, 28.11.

IEA(2014), $\mathrm{CO}_{2}$ emissions from fuel combustion, Highlights, International Energy Agency, Edition.

INSEE (2010), Taux d'indépendance énergétique nationale en 2010.

Institut international de l'énergie nucléaire (I2EN), http://www.i2en.fr.

IRENA (2015), Renewable Energy and Jobs. Annual Review 2015, International Renewable Energy Agency.

JORF (2015), Décret $n^{\circ} 2015-361$ du 30 mars 2015 modifiant le décret $n^{\circ} 2014-1672$ du 30 décembre 2014 instituant une aide à l'acquisition et à la location des véhicules peu polluants, Journal officiel de la République française $n^{\circ} 0076$ du 31 mars 2015. 
Loi $n^{\circ}$ 2009-967, du 3 août 2009 de programmation relative à la mise en śuvre du Grenelle de l'environnement (1), version consolidée au 01 juillet 2010.

MÉDDÉ (2009), Part et évolution des secteurs, 22 septembre 2009, http://www.developpement-durable.gouv.fr/Part-et-evolution-des-secteurs.html.

MÉDDÉ (2014a), Ségolène Royal présente le projet de loi relatuf à la transition énergétique pour la croissance verte 30 juillet 2014, Ministère de l'Écologie, du Développement Durable et de l'Énergie, http://www.developpement-durable.gouv.fr/Segolene-Royal-presente-le-projet.html.

MÉDDÉ (2014b), Une loi en faveur du développement des bornes de recharge pour véhicules électriques 29 juillet 2014, Ministère de l'Écologie, du Développement Durable et de l'Énergie.

MÉDDÉ (2015), Mise en place du nouveau bonus voiture électrique et hybride: jusqu'à 10.000 euros pour la mise à la casse d'un vieux diesel, 4 avril 2015, http://www.developpement-durable.gouv.fr/ Mise-en-place-du-nouveau-bonus, 42952 .html.

MÉDDTL (2011), Plan national d'adaptation de la France aux effets du changement Climatique 2011-2015, Ministère de 1'Écologie, du Développement Durable des Transports et du Logement (MEDDTL).

Młynarski T. (2013), Francja w procesie uwspólnotowienia bezpieczeństwa energetycznego i polityki klimatycznej Unii Europejskiej, Kraków.

Mlynarski T. (2013), Partnerstwo czy nierównowaga? Francja wobec rosnacej pozycji Niemiec w Unii Europejskiej, Instytut Zachodni, nr 128, Poznań, http://www.iz.poznan.pl/news/ 653_FR-DE\%20nierownowaga.pdf, 15.07.2015.

Présidence de la République (2014a), Principales decisions du l6eme Conseil des Ministres franco-allemand, Paris, 19 février.

Présidence de la République (2014b), Releve de decisions Conseil Des Ministres Franco-Allemand. 19 fevrier.

Réseau „Sortir du nucléaire” (2015), Transition énergétique: le Sénat fixe le plafond de production du nucléaire à $64,85 \mathrm{GW}$, http://www.sortirdunucleaire.org/Transition-energetique-le-Senat-fixe-le-plafond.

Sénat RF (2015), Projet de loi relatuf à la transition énergétique pour la croissance verte, 15 juillet 2015, http://www.senat.fr/petite-loi-ameli/2014-2015/530.html, 15.07.2015.

Szarka J. (2011), France's troubled bids to climate leadership, w: The European Union as a Leader in International Climate Change Politics, red. R. K. W. Wurzel, J. Connely, Routledge/UACES.

„Le Monde" (2014), Transition énergétique: dix milliards d'aides publiques sur trois ans, 29.07. http://www.lemonde.fr/planete/article/2014/07/29/transition-energetique-dix-milliards-d-aides-publiques-sur-trois-ans_4464093_3244.html, 20.06.2015.

\section{Streszczenie}

Dotychczasowa polityka energetyczna Francji była skoncentrowana na efektywności energetycznej i standardach bezpieczeństwa energetyki jądrowej, w mniejszym stopniu zaś na rozwoju nowych zielonych źródeł energii. W ramach nowej polityki transformacji energetycznej, zaproponowano wiele inicjatyw w zakresie rozwoju energetyki odnawialnej, zbliżając się do niemieckiej wizji transformacji energetycznej. Francuskie elity polityczne uznały, że rozwój OZE ma znaczenie strategiczne nie tylko dla zaspokojenia potrzeb energetycznych kraju, ale 
także - w obliczu zaostrzania reżimu ograniczenia emisji gazów cieplarnianych (GHG) - jest szansą na zbudowanie przewagi konkurencyjnej innowacyjnej gospodarki i stworzenie wielu nowych miejsc pracy. W efekcie, ekologiczna modernizacja gospodarki przez nieemisyjne innowacje technologiczne ma zapewnić postęp w osiagnięciu celów środowiskowych z jednoczesnym postępem industrialnym i wzrostem gospodarczym (sustainable development).

Słowa kluczowe: transformacja, polityka energetyczna, Francja, ekonomia

\title{
The determinants of the transformation of energy policy in France. Between ecological modernisation and economic calculations
}

\begin{abstract}
Summary
The project of ecological modernisation - widely integrating all aspects of economic transformation - is one of the flagship ideas of incumbent French President François Hollande and the French Socialists. The current energy policy of France, one of the largest global and European energy consumers, is focused on energy efficiency and technological safety standards in the nuclear industry, and to a lesser extent on the development of new green energy technologies. Approaching the German vision of energy transformation, the new French policy has proposed several initiatives for the development of renewable sources. France realised that the development of renewable energy is of strategic importance, not only to meet the energy needs of the country, but also - in the face of the stricter regime of GHG emissions reductions - to provide a competitive advantage for an innovative economy and an opportunity to create many new jobs. Ecological modernisation of the economy is supposed to ensure progress in achieving environmental goals, together with the progress of industrialisation and economic growth (sustainable development).
\end{abstract}

Key words: transformation, energy policy, France, economy 
